\title{
口底癌の治療成績
}

\author{
笹栗正明・大関悟・岡本学 \\ 原広子・田代英雄
}

\section{Treatment for squamous cell carcinoma of the floor of the mouth}

\author{
Masaaki Sasaguri - Satoru Ozeki - Manabu OKamoto \\ Hiroko Hara - Hideo Tashiro
}

Abstract: During a period of 22 years, from 1963 to 1984, 45 primary patients with squamous cell carcinoma of the floor of the mouth were treated at the Department of Oral Surgery, Kyusyu University. Of these 45 patients, 38 (84.4\%) were male.

According to the TNM-classification of the UICC (1978), 9 cases were T1, 23 were T 2 and 7 were $T 3$. The other 6 cases were classified $T 4$ because of massive tongue and bone invasion. In stage grouping, 7 cases belonged to stage I, 11 to II, 13 to III and 14 to IV. In 30 cases, the primary lesions of the floor of the mouth arose in the anterior part to bilateral canines, and in 15 cases in the posterior part. In most instances the lesions were ulcerated, and particularly endophytic type with deep ulceration were seen in advanced condition.

In principle, squamous cell carcinomas of the floor of the mouth were treated in our department as follows; In stage I - II cases, interstitial radium therapy or resection only was performed. Stage $\mathbb{I I} \cdot$ IV cases received surgical treatment combined with preoperative external radiaton and bleomycin. When the primary lesion was controlled by this combined therapy radiation and bleomycin, surgery was not performed. Five cases of 7 in $T 3$ category were treated only with this combined therapy without surgical treatment.

The reconstruction of oral cavity after en bloc operation were performed with cervical island skin flap in most $\mathrm{T} 2$ cases, and segmental mandiblectomy or subtotal glossectomy was followed by the reconstruction with Pectoralis Major Myocutaneous flap.

Of 6 recurrent cases, 4 patients died of primary lesion recurrence, one died of other illness and one is alive. Metastasis to the cervical lymph nodes were histologically confirmed in 15 cases. Secondary and bilateral metastasis was noted in 5 and 4 cases respectively.

The survival rate in all cases was $61.9 \%$ by 5 years $(\mathrm{T} 1,63.7 \% ; \mathrm{T} 2,65.2 \% ; \mathrm{T} 3$, $71.3 \% ; \mathrm{T} 4,42.8 \%$ ), 5 years survival rate was $67.4 \%$ in cases treated by interstitial radium therapy, $63.2 \%$ by combined therapy of radiation and bleomycin, $62.2 \%$ by surgery combined with preoperative radiation and bleomycin. The survival rate was significantly higher in cases without metastasis $(78.6 \%)$ compared with cases with metastasis (38.6\%).

Key words: carcinoma of the floor of the mouth, therapeutic modality, result of treatment

九州大学险学部口腔外科学第 1 腹座

（主任：田代英雄教授）

First Department of Oral Surgery, Faculty of
Dentistry, Kyusyu University (Chief: Prof. Hideo Tashiro)

受付日：昭和 62 年 3 月 23 日 
緒

言

口底は，舌と下顎骨に囲まれたU字型の㹨い領域で， 口底粘膜は外側は下䫇歯肉粘膜に，内側は舌粘膜へと連 続し，後方は前口蓋弓へと移行している。また口底粘膜 下では，顎舌骨筋を介して顎下榢へ移行する。このよう な口底の解剖学的特徵のため, 口底癌は比較的早期より 隣接周囲組織へ浸潤, 進展する ${ }^{1)}$ 。また, 口底は舌運動, 咀謝に重要な役割を有しており, 治療にあたって機能保 存といら面でも難しい部位であり，放射線治療による顎 骨の後障害や手術による機能障害などの問題をかかえて (る2)

当教室の症例をみると，治療法は時代とともに大きく 変化してきており，特に近年の化学療法や再建法の進步 により, 術後の口腔の形態・機能をかなりの程度まで回 復しらるよらになった。 そこで, 当教室において治療し た口底扁平上皮癌一次症例を対象として臨床的観察と治 療法および，治療成績の検討を行い，当教室における最 近の治療方針を提示した。

\section{対 象 症 例}

1963年 1 月から 1984 年12月までの 22 年間に九州大学附 属病院口腔外科において, 治療した口底扁平上皮癌一次 症例45例を対象とした。これは同期間に当科にて治療を 行った口腔扁平上皮癌一次症例 353 例の $12.7 \%$ に相当す る(図 1)

性別は男性38例，女性 7 例で，男性が $84.4 \%$ と压倒的 に多かった，初診時年秢は男女とも50歳台がピークで， 平均年龄は男性 57.8 歳，女性53.7歳であった。1 日20本 以上の掣煙者は $84.4 \%$ であり（図 2)，毎日飲酒の習慣 のあるものは $64.4 \%$ であった。

結果

\section{1. 臨床所見}

発現部位は，下顎犬函遠心面を境に口底を前方部，左 右後方部に分けると, 前方部30例，後方部15例で前方部 $66.7 \%$ ，右後方部 $20.0 \%$ ，左後方部 $13.3 \%$ であった（図 3).

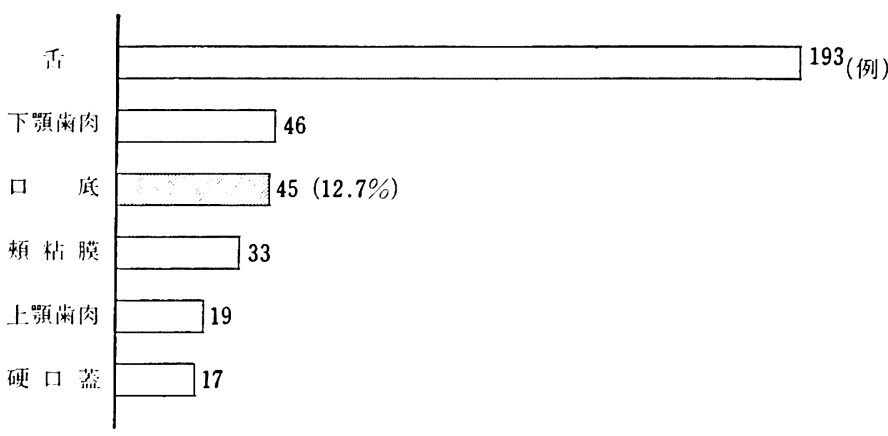

図 1 口腔扁平上皮癌新鮮例部位別症例数（1963～1984）

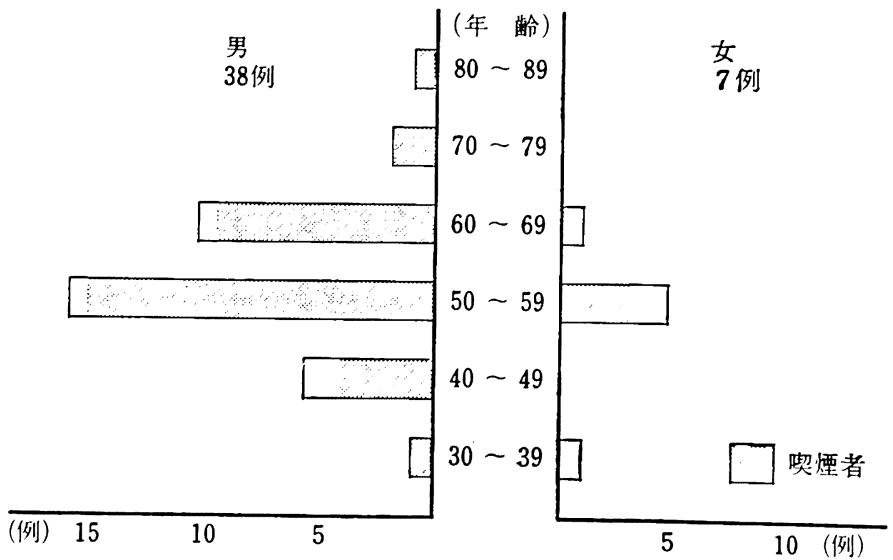

図 2 口底癌年龄別症例数 


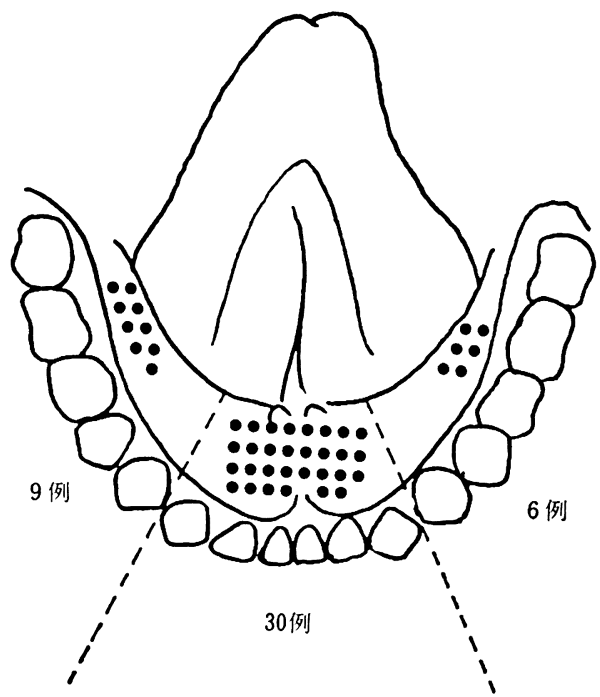

図 3 部位別症例数

肉眼的腫瘍型 (大部の分類 ${ }^{3)}$ ) は, 白板型 2 例, 肉 芽型 4 例, 腫瘤乳頭腫型11例, 潰瘳びらん型 8 例, 潰瘍 硬結型10例，浸潤硬結型10例で，一般に進展例では深部 への潰瘍形成と周囲に硬結を伴ら内向発育型が多く認め られた。

腫瘍の進展度を1978年 UICC の分類 ${ }^{4)}$ でみると，T1 9 例, T2 23例, T3 7 例, T4 6 例であり, T4 6 例 の5ち舌の運動障害 4 例, 靧下部皮成浸潤 1 例, 下筫骨 浸潤が 1 例であった。

頸部リンパ節については， N0 18例， N1 18例， N2 3 例，N3 6 例であり，遠隔転移の明らかな症例はなか った. Stage 分類では Stage I 7 例, Stage II 11例, Stage III 13例, Stage IV 14例で Stage III IV の進展 例 が多くみられた（表1）．N1〜327例の5ち組織学的 に転移を認めたものは10例で，この5ち4例に両側転移 を認めた。N0 18例のらち 5 例に後発転移が起こった。

\section{2. 治療法}

原発巣に対する一次治療は，1974年までは，主として 組織内照射や手術のみによるものであったが，1975年以 降 bleomycin (BLM) などの化学療法が組み入れられ， 放射線療法・化学療法・手術の三者作用療法が多く行わ れるよらになった（表 2).

Stage I ・II の症例に対しては, 組織内照射主体11例, 外照射と化学療法併用 3 例, 手術単独 3 例, 1 例に外照 射と化学療法と手術の三者併用療法を行った。 Stage III NVの症例では， N0 症例はなく，いずれもN 1 〜 3 であ ったので, 頸部郭清と原発巣を一塊とした en bloc 手 術を行ったものが多い， T1，T2 14例のうち術前に外 照射と化学療法（主にBLM）との同時作用（三者併用 療法）を行ったものは 6 例で, 術前に単独照射あるいは
表 1 口底癌 TNM 分類 (1963 1984)

\begin{tabular}{c|r|r|r|r|r}
\hline & T 1 & T 2 & T 3 & T 4 & 計 \\
\hline N 0 & 7 & 11 & & & 18 \\
N 1 & 1 & 9 & 3 & 5 & 18 \\
N 2 & & 2 & 1 & & 3 \\
N 3 & 1 & 1 & 3 & 1 & 6 \\
\hline 計 & 9 & 23 & 7 & 6 & 45 (例) \\
\hline
\end{tabular}

すべて MO

表 2 口底癌 Stage 別治療法

\begin{tabular}{r|r|r|r|r|r}
\hline & I & II & III & IV & 計 \\
\hline $\mathrm{O}+\mathrm{O}$ & 2 & 1 & & & 3 \\
$\mathrm{C}+\mathrm{O}$ & & 1 & 1 & 1 & 3 \\
$\mathrm{R}+\mathrm{C}+\mathrm{O}$ & & 1 & 4 & 7 & 12 \\
\hline $\mathrm{N}$ & 3 & 5 & 1 & & 9 \\
$\mathrm{C}+\mathrm{N}$ & 1 & 1 & 2 & & 4 \\
$\mathrm{C}+\mathrm{R}$ & 1 & 2 & 3 & 5 & 11 \\
\hline 計 & 7 & 11 & 13 & 14 & $45($ (例)
\end{tabular}

$\mathrm{O}$; 原発栄手術 $\mathrm{N}$; 組織内照射

$\mathrm{R}$; 外照射 $\mathrm{C}$; 化学療法

化学療法単独が 5 例に行われた。 T 3 症例 7 例のらち 5 例は外照射と化学療法により腫瘍は消失し，5ち2 例は リンパ節腫大も消失した。 1 例は組織内照射と化学療 法，1例は外照射と手術を行った。 T4 6 例中 5 例に三 者併用療法を行っている，残り 1 例は，外照射と化学療 法が奏効したため手術を行わず経過を観察したが，原発 单は制御できたと思われたものの遠隔転移のため 1 年 6 か月後に死亡した。

下靧骨の処置は，原発巣に対して手術を施行した21例 中, 骨への浸潤の認められた 5 例で区域切除を行い, 盾 瘍が齿肉にかかっていたものの骨浸潤が明らかでなかっ た 5 例には辺縁切除を行った。

当教室に拈ける最近の口底癌の治療方針は図4のごと くである，T 1 N 0 で表在性のものは，手術のみを行ら こともあるが，一般に T $1 ， 2$ でN 0 症例に対しては, 可 及的に組織内照射を行っている，T 2 で比較的大きく歯 肉にかかり組織内照射が困難な症例や T 3，4 およびN $1 \sim 3$ 症例では術前にまず BLM と放射線の併用療法を 行っている。併用方式は原則として BLM 1 回 $10 \mathrm{mg}$ 筋注後 ${ }^{60} \mathrm{Co} 1.5 \mathrm{~Gy}$ の外照射を行い， 3 週間に ${ }^{60} \mathrm{Co}$ $22.5 \mathrm{~Gy}$ と BLM $110 \mathrm{mg}$ を 1 クールとしている. 畽瘍 の消失した症例で手術を行わず，口内炎の消退後さらに 2 週間（総量 $37.5 \mathrm{~Gy}, 170 \mathrm{mg}$ ）の追加併用で経過を 


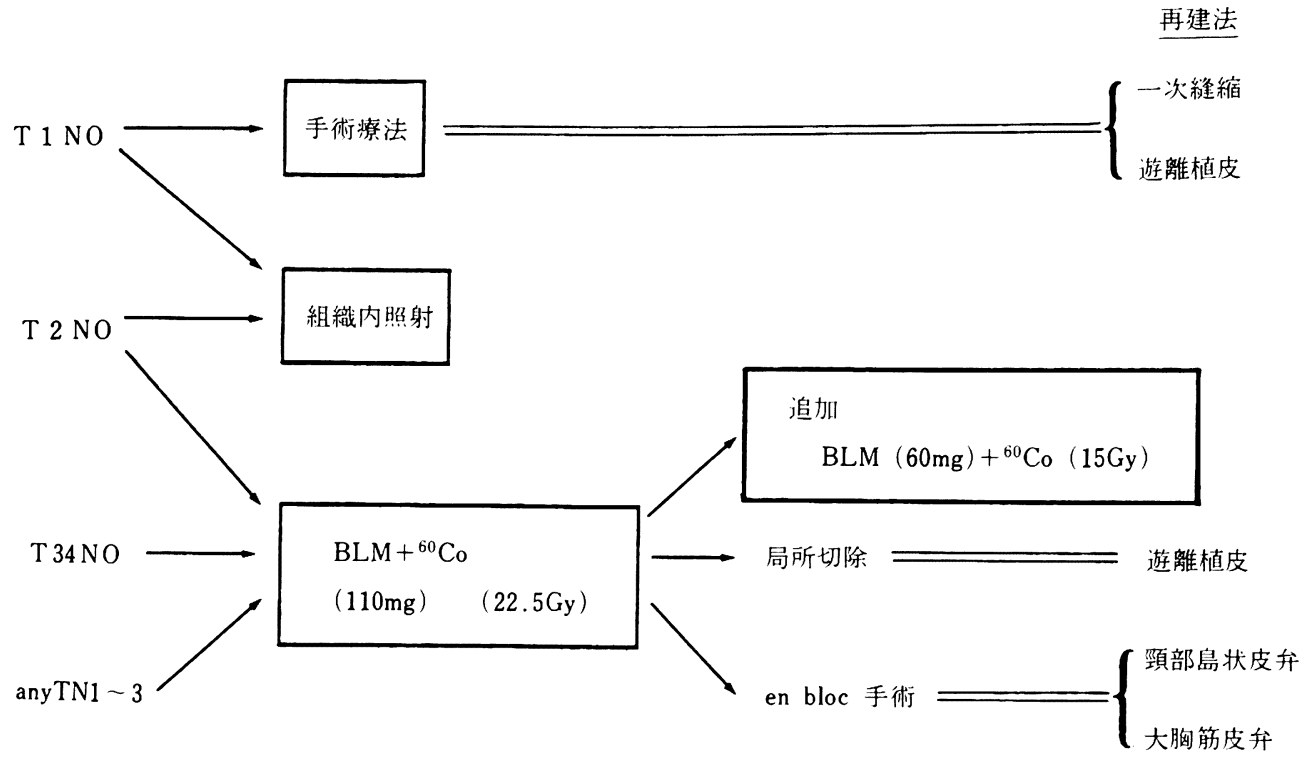

図4 口底瘦当科に拈ける最近の治療方針

表3口底癌再建方法

\begin{tabular}{l|c|c|c|c|c}
\hline & T 1 & T 2 & T 3 & T 4 & 計 \\
\hline 一次縫縮 & & & & 1 & 1 \\
遊離皮弁 & 3 & 2 & & & 5 \\
舌 台 & & 1 & & & 1 \\
頸部島状皮弁 & & 7 & & 1 & 8 \\
大胸笳皮弁 & & & & 3 & 3 \\
\hline \multicolumn{1}{c|}{ 計 } & 3 & 10 & 0 & 5 & $18($ (例) \\
\hline
\end{tabular}

みたものが10例あり，このうち 3 年以上の局所制御率は $70.0 \%(7 / 10)$ であった。腫瘍が残存していると考えら れた場合には，手術を行っているが，頸部リンパ節転移 のある症例では，原発巣と頸部を一塊として切除する en bloc 手術を施行することが多い.

頸部リンバ節に対しては，原発巣に対し外照射を行う 場合には，転移の疑われるリンパ節も照射野に含めてお り，照射後頸部垶清を施行しているが，初診時N 1〜3 症例27例中外照射によりリンバ節が消失した 4 例は，頸 部郭清は施行せず経過を钼察したが，そのうち 1 例に 1 年 6 か月後にリンパ節転移再発を認めた。

再建方法は，切除籁囲により様々であるが，今回の症 例ではT 1 症例では一次縫縮または遊離植皮を行い， $\mathrm{T}$ 2, T 3 症例で en bloc 手術を行わなかった症例では, 遊離植皮を行った. en bloc 手術を行った症例では, T2 10例中 7 例が頸部島状皮弁, 2 例が遊離植皮, 1 例が舌 弁を用いた，大胸筋皮弁を用いた 3 例はいずれも T 4 症 例であり，2 例は舌覀全摘，1例は下顎骨区域切除を行

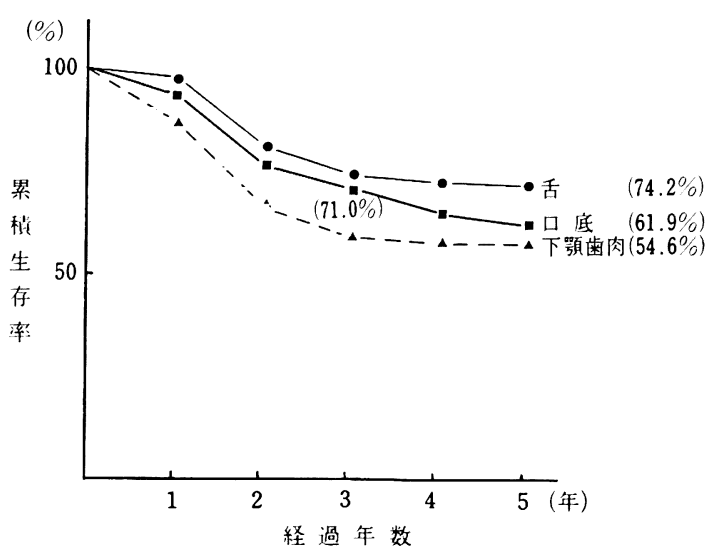

図 5 口底癌累皘生存率

い下顎骨の再建のため, 肋骨付大胸勄皮弁とした（表 3 ).

\section{3. 治療成績}

口底癌一次症例 45 例の治療成績は, 累積生存率で 1 年 $93.3 \%, 2$ 年76. $3 \%, 3$ 年 $71.0 \%, 4$ 年 $65.2 \%, 5$ 年 $61.9 \%$ であった（図 5 ).

$\mathrm{T}$ 別 5 年累積生存率は T $163.7 \%, \mathrm{~T} 265.2 \%, \mathrm{~T} 3$ $71.3 \%, \mathrm{~T} 442.8 \%$ であり, 統計学的に有意差は認めな かった (図 6).

原発䉓に対する治療法別の 5 年累積生存率は, 組織内 照射主体群 $67.4 \%$, 外照射, 化学療法併用群 $63.2 \%$, 外 照射・化学療法・手術三者併用療法群 $62.2 \%$, 手術主体 群 $57.4 \%$ であり, 統計学的に有意差は認めなかった。 


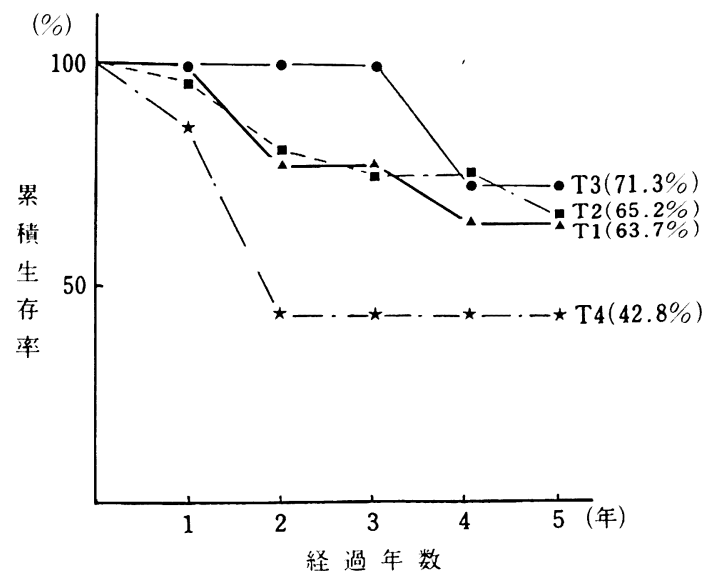

図 6 口底癌 $\mathrm{T}$ 別累積生存率

初診時に頸部リンパ節転移陽性例および後発転移も含 め, 経過中に頸部リンパ節に組織学的に転移を認めた症 例の 5 年累積生存率は $38.6 \%$ であり，転移を認めなかっ たものは78.6\%であり統計学的に有意差が認められた。

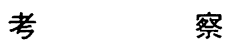

\section{1. 対象症例}

対象症例は男性38例, 女性 7例で男女比は5.4:1と男 性がかなり多く，他の報告とほほ同様の傾向を示してい $ろ^{2,5 \sim 12)}$.

発生部位は，口底癌は舌小帯付近に好発するといわれ ており ${ }^{11)}$ ，われわれの症例でも前方部 $66.7 \%$ で他 の 報 告 ${ }^{2)}$ と同様の傾向を示した。

原発巣の進展度についてみると， T 3， T 4 の進展例 が多いとの報告が多くみられる。底は舌のように直接 運動に関与していないため疼痛の発現が遅く，また下顎 蒾肉と舌により視野が妨げられ発見が遅れるため, 比較 的進行した状態で来院するものが多いといわれている がわれわれの症例では T 2 症例が 23 例と約半数を占 め, T 19 例, T 37 例, T4 6 例とほぼ同数で他部 位と比較して, 原発巣については進展例が多いといら傾 向は認められなかった。

初診時のリンパ節転移に関しては，諸家の報告はまち まちであり，Campos ら ${ }^{13)}$ は21\%が転移陽性であったと し，井上 ${ }^{14)}$ は67\%が転移陽性であったと報告している。 われわれの症例では，臨床的に転移陽性としたものは60 \%であり堀内ら や井上 ${ }^{14)}$ と同様の傾向を示した．

経過中のリンパ節転移について Campos ら ${ }^{13)}$ は, 初 診時転移陰性例63例中13例 $(20.6 \%)$ に転移が認められ たと報告している，われわれの症例では，N0 18例中 5 例 $(27.7 \%)$ に後発転移が起こった。 5 例中 4 例は 1 年 以内に転移を認めて扣り，この期間における戦重な観察 が必要である15) また初診時N $1 \sim 3$ と判定し組織学的
表 4 口底瘦頸部リンパ節転移頻度

\begin{tabular}{c|c|c|c}
\hline & $\mathrm{N} 0 \rightarrow \mathrm{N}+$ & $\mathrm{N} 1 \sim 3 \rightarrow \mathrm{N}+$ & \multicolumn{2}{|c}{ 計 $(\%)$} \\
\hline $\mathrm{T} 1$ & $7 \rightarrow 2$ & $2 \rightarrow 1$ & $3 / 9(33.3)$ \\
$\mathrm{T} \mathrm{2}$ & $11 \rightarrow 3$ & $12 \rightarrow 3$ & $6 / 23(26.1)$ \\
$\mathrm{T} \mathrm{3}$ & & $7 \rightarrow 3$ & $3 / 7 \quad(42.9)$ \\
$\mathrm{T} \mathrm{4}$ & & $6 \rightarrow 3$ & $3 / 6 \quad(50.0)$ \\
\hline 計 & $5 / 18$ & $10 / 27$ & $15 / 45(33.3)$ \\
\hline
\end{tabular}

$\mathrm{N}+$; 組織学的転移症例

に転移陽性であった症例は27例中10例で，結局45例中15 例 (33.3\%) が転移陽性であった（表 4 ）. N 1 3 3で 組織学的に17例が転移陰性であり，63.0\%が為陽性であ った。このようにロ底癌が舌やその他の部位と比較して 偽陽性が多かった原因としては，（1）顎下腺管の閉塞に よって，顎下腺が硬化した場合顎下腺とリンパ節の判定 がつきにくい13)，(2) 買下部之畽瘍の存在する口底が近 接しており，炎症性反応性腫大と，転移によるリン八節 の腫大の鑑別が困難であった，（3）口底は軟組織中に位 罚し，非常に早期にリンパ節に浸潤し，頸部に抎大する 傾向がある(16)ため，触知するリンパ節に転移があるかど らか迷ら場合は積極的に転移ありと判定したこと，(4) 原発巣に術前外照射を行う際，転移巣まで含めた照射を 行うことが多いので，それにより転移巣が消失した可能 性などが考えられる。

\section{2. 原発巣の治療}

口底癌の治療は, 形態・機能保存の問題を含み, 各施 設によりさまざまな報告があるが, Porter ${ }^{17)}$, Campos $5^{13)}, \mathrm{Chu} 5^{18)}$, 堀内 $5^{7)}$, 和田 $5^{8)}$ は放射線治療を一 次治療として推奖している。

堀内ら によよれば,ごく初期の症例では局所切除です よいが，それ以外は手術では侵襲が大きく機能障害の点 からも放射線治療が最適であると述べている。

一方，斎藤ら ${ }^{9)}$ の報告では放射線治療による成績は必 ずしも良好であるとはいえず，照射障害を高率に併発し やすいなどの理由から，手術主体の治療法を行ってい る.

Helfrich $5^{12)}$, Harrold ${ }^{5)}$, Barton ${ }^{19)}$ 女手術主体の治 療を行っており, Helfrich ら ${ }^{12)}$ は放射線治療では局所は 制御できても頸部リンパ節をほとんど制御できないと述 ベている.

Applebaum ら ${ }^{20}$ によれば，放射線治療単独, 手術単 独よりも，放射線治療との併用による composite operation により 3 年生存率 $62 \%$ と，良好な結果が得られた と述べている。

井上ら ${ }^{10)}$ ，小浜ら ${ }^{1)}$ は病期により治療法を選択して扰 り，井上ら ${ }^{10)}$ は Stage I ・II に対しては放射線治療を主 体とし, Stage III には放射線治療を第一選択とし，䀒瘍 
残存例には手術を併用している，Stage IV では放射線単 独, 手術単独, 両者併用のいずれでも腫瘍制御は困難で あり化学療法, 免疫療法の併用が必要であると述べてい る. 小浜ら ${ }^{1)}$ は Stage I ・ II には化学療法を行った後, 局所切除また症例によっては上頸部リンパ節を含む en bloc 手術を行い, Stage III IV の症例では, 化学療法後 に頸部郭清とともに en bloc 手術を行い，化学療法が 奏効しなかった症例には外照射を追加した後に手術を行 らと述べている。

当科の治療方針としては図4 亿示すごとくである．今 回の症例でもStage I ・II 対しては，組織内照射を主 とする放射線治療を主体として行い， Stage IIIでは，1 例のみ組織内照射単独症例があったが，他は全て併用療 法を行っている. Stage $V$ では，化学療法・放射線療法 (外照射)・手術の三者併用療法が主体である。一応,

Stage II ・IV の症例には三者併用療法を前提としている が，BLM $110 \mathrm{mg}$ と ${ }^{60} \mathrm{Co} 22.5 \mathrm{~Gy}$ 外照射併用療法後， 畽瘍の消失, リンパ節の消失をみたものはさらに BLM と ${ }^{60} \mathrm{Co}$ 外照射の追加を行い, 手術を行わず啟重な経過 観察を行っている. Stage II ・IV で27例中 8 例が BLM と外照射のみであるが，1例のみ原病死 (遠隔転移), 1 例は他病死で他の例は良好な経過をとっている.

口底は放射線に対する組織耐容性が舌に比べ著しく劣 る ${ }^{8)}$ ため放射線障害の点からも ${ }^{60} \mathrm{Co}$ 外照射之 BLM 併 用による線量減少は大変有用であるといえる。田中21)は 雨肉癌での外照射と BLM との併用効果について，60 $\mathrm{Gy} / 6 \mathrm{~W}$ は $30 \mathrm{~Gy} / 3 \mathrm{~W}+\mathrm{BLM} 90 \mathrm{mg}$ 併用と等価であ ると推論しており，当科の併用方式では，1 クール ${ }^{60} \mathrm{Co}$ 外照射 $22.5 \mathrm{~Gy} / 3 \mathrm{~W}+\mathrm{BLM} 110 \mathrm{mg}$ は放射線単独 40 Gy/4Wに, 追加併用 ${ }^{60} \mathrm{Co}$ 外照射 $37.5 \mathrm{~Gy} / 5 \mathrm{~W}+\mathrm{BLM}$ $170 \mathrm{mg}$ は放射線単独 $60 \mathrm{~Gy} / 6 \mathrm{~W}$ の治療効果に相当す るとみなしている。今回併用療法を行った症例にはほと んど骨障害はみられなかった。

全症例の 5 年累積生存率は61.9\%で，これは口腔癌の なかで舌癌の $74.2 \%$ に次いで良い成績であった。ちなみ に下顎歯肉癌は54.6\%であった。

各治療法別での 5 年累積生存率は, 組織内照射主体群 $(67.4 \%)$, 化学療法・外照射併用群 $(63.2 \%)$, 三者併 用群 $(62.2 \%)$, 手術主体群 (57.4\%) となっているが, 統計学的有意差は認められず，現在のわれわれの治療方 針では一応満足のゆく結果が得られているものと考え る.

術後の再建法は，早期の表在性 Stage I ・ II の症例は 一次縫縮あるいは遊離植皮を行っている，口底部の欠損 の場合, 舌粘膜を引きよせることにより, さらに䊝槽骨 が切除されている場合は，煩粘膜と縫合することによ り，かなりの久損でも一次縫縮が可能である. しかし， 舌の運動が制限され機能障害を残す。また en bloc 手 術の場合は，口腔と頸部創との閉鎖，買下部の死腔の閉
鎖も必要となってくる。

当科では, en bloc 手術を行った症例に対しては, Farr ら ${ }^{22)}$ による頸部島状皮弁を用いることが多く，T4 など欠損の大きい症例では大胸筋皮弁, 罘骨の再建も行

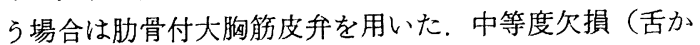
下顎骨の一部を含めた口底半切）の再建に対して大胸筋 皮弁では組織量が過剰であることもあり, 手術侵襲の大 きさからして，この頸部島状皮弁が大変有用であっ た23).

\section{3. 頸部リンパ節転移}

頸部リンパ節の転移は予後を決定する重要な因子であ り，5年生存率でも頸部リンパ節転移陰性のものは78.6 \%, 初診時および経過中に転移の認められたものは38. 6 \%と明らかに差を認めた。頸部りンパ節転移に対する治 療は, 根治的頸部郭清術が最も確実な治療ではあるが, 転移様相によっては郭清術のみでは再発をきたしやすい

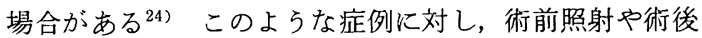
照射を行らことによって再発率が抑えられるという報 告 ${ }^{35}{ }^{26)}$ が多くみられる.

口底は顎下部に近接しているため, 原発巣の照射の際 に頸部転移巣を含め照射することが多いが，BLM と放 射線との併用療法では頸部リンバ節転移に対する組織学

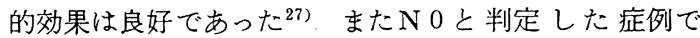
も，原発巣の大きさや組織型から転移をきたしやすい夕 イプには，上頸部を含めた予防照射を積極的に行ってい る.

\section{ま と め}

九州大学附属病院口腔外科において1963年から1984年 までの 22 年間に治療を行った口底扁平上皮癌一次症例 45 例について, 臨床病態像, 治療法, 治療成績について検 討した。

1. 対象症例は, 男性38例, 女性 7例で男女比 $5.4: 1$ と男性が圧倒的に多かった。

2. 1978年の UICC の分類による腫晹の進展度では, $\mathrm{T} 19$ 例, T 2 23例, T3 7 例, T4 6 例, Stage 別て は, Stage I 7 例, Stage II 11例, Stage II 13例, Stage IV 14例であった。

3. 当科に扣ける口底癌の治療方針は, Stage I ・ II に 対しては，手術単独あるいは組織内照射を主体として行 い, Stage III ・ IV では化学療法・放射線療法（外照射） の併用後，手術を行う三者併用療法が主体である。

4. 再建については, 中等度欠損に対し頸部島状皮弁 が有用であった。

5. 全症例の累積生存率は 3 年 $71.0 \%, 5$ 年 $61.9 \%$ で あった。 各治療法別での 5 年累積生存率は, 組織内照射 主体群 $67.4 \%$, 外照射 - 化学療法併用群 $63.2 \%$, 外照射 - 化学療法 - 手術三者併用群 $62.2 \%$, 手術主体群 $57.4 \%$ 
であった

本論文の要旨は第 4 回口腔腫瘍研究会（札幌，1986） に拈いて発表した。

\section{引用文 献}

1）小浜源郁, 岩井正行, 他：口腔腫瘍の臨床。第 1 版, 書林, 東京, 1985, 103-112頁.

2) 福武洋二, 壬木 寛, 他: 大阪读科大学口腔外科 学教室および放射線学教室に扣ける悪性腫瘍患者 の治療と予後について一第 4 報口腔底瘦一。日口 外誌 29：404-410 1983.

3）大部大明. 口腔粘膜扁平上皮癌の臨床的研究一治 療後の経過を中心として一 日口外誌 19：4064341973.

4) Harmer, M.H.: TNM Classification of Malignant Tumors. $3 \mathrm{rd}$, UICC, Geneva, 1978, p 23-26.

5) Harrold, C.C.: Management of cancer of the floor of the mouth. Am J Surg 122: 487-493 1971.

6) Fayos, J.V.: Management of squamous cell carcinoma of the floor of the mouth. Am J Surg $123: 706-7111972$.

7）堀内淳一, 奥山武雄：煩粘膜 - 口腔底・下顎㳡肉 扁平上皮癌の放射線治療の成績とその検討。日医 放会誌 34: 739-751 1974.

8）和田卓郎, 淵端孟, 他: 口腔底瘦の放射線治 療。日医放会誌 35：759-768 1975.

9）斎藤裕男，小野勇，他：口腔底扁平上皮癌の治 療。日耳鼻 88：1659-1665 1985.

10）井上健造, 藤谷哲造, 他：口腔底癌の臨床的考察 一治療成績扰上び予後について一 日耳奥 88 ： 1673-1677 1985.

11) Mashberg, A. and Meyers, H.: Anatomical site and size of 222 early asymptomatic oral squamous cell carcinomas. A continuing prospective study of oral cancer II . Cancer 37: 2149-2157 1976.

12) Helfrich, G.B., Nickels, M.E., et al.: Management of cancer of the floor of the mouth. Am J Surg 124: 559-562 1972.

13) Campos, J.L., Lampe, I., et al.: Radiotherapy of the floor of the mouth. Radiology 99: 6726821971.
14）井上慧文：口底癌の治療について。耳鬼臨床 70 ： 99-105 1977.

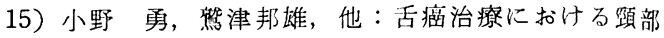
郭清術の評価. 癌臨：123-130 1980.

16）上野正，岡達，他. 口腔癌の治療と予後に 関する研究（第 4 報）口底癌32例について。只外 誌 9: 65-69 1963.

17) Porter, E.H.: The local prognosis after radical radiotherapy for squamous carcinoma of the alveolus and of the floor of the mouth. Clin Radiol 22: 139-143 1971.

18) Chu, A. and Fletcher, G.H.. Incidence and cause of failures to control by radiation the primary lesion in squamous cell carcinomas of the anterior two-thirds of the tongue and floor of mouth. Am J Roentgenol 117: 502-508 1973.

19) Barton, R.T.: Surgical treatment of carcinoma of the floor of the mouth. Surg Gynecol Obst 133: 971-972 1971.

20) Applebaum, E.L., Callins, W.P., et al.: Carcinoma of the floor of the mouth. Arch Otolaryngol 106: 416-421 1980.

21）田中義弘：菻肉癌の放射線治療に関寸る臨林的研 究一特に放射線・ブレオマイシンの同時併用効果 について一 日医放会誌 37：1132-1143 1977.

22) Farr, H.W., Jean-Gilles, B., et al.. Cervical island skin flap repair of oral and pharingeal defect in composite operation for cancer. Am J Surg 118: 759-763 1969.

23）田代英雄, 大関 悟: Cervical island skin flap に上るロ腔癌切除後の即時再建. 日口外誌 28 : 1106-1113 1982.

24) Ozeki, S., Okamoto, M., et al.. Cervical recurrence following radical neck dissection for carcinoma of the oral cavity. Fukuoka Acta Medica 76: 37-42 1985.

25) Strong, E.W.: Preoperative radiation and radical neck dissection. Surg Clin North Am 49: 271-276 1969.

26) Vikram, B., Strong, E.W., et al.: Failure in the neck following multimodality treatment for advanced head and neck cancer. Head \& Neck Surg 6: 724-729 1984.

27）大関悟，岡本学，他：口腔癌の頙部リンハ笛 転移巣に対寸方放射線・Bleomycin 併用療法の効 果. 日癌治 21：82-88 1986. 